\title{
Progressivity Of Criminal Handling Fraud And Disease By The Directorate Of The General Criminal Reserse Of Central Java Regional Police (POLDA)
}

\author{
Ni Made Srinitri ${ }^{1}$, Umar Ma'ruf $^{2}$ and Munsyarif Abdul Chalim ${ }^{3}$
}

Abstract. This study aims to determine and analyze the process of handling fraud and embezzlement by Central Java Regional Police Criminal Investigation investigators and the progress of handling fraud and embezzlement crime at the Central Java Regional Police Criminal Investigation Directorate. The approach method used is empirical juridical with descriptive analytical research specifications. The data used in the form of primary data and secondary data so that the method of data collection through field studies and literature studies. Data analysis method used is qualitative analysis. As a knife of analysis, the concepts of restorative justice, legal system theory and progressive legal theory are used.

The results of the study concluded that the process of investigating fraud and embezzlement in the East Java Regional Police Criminal Investigation Directorate was in accordance with the provisions of the Criminal Procedure Code and the National Police Chief Regulation Number 6 of 2019 on Criminal Investigations. The progress in handling fraud and embezzlement in the Central Java Regional Police Criminal Investigation Directorate is related to the application of restorative justice in investigating criminal acts that starts with two components of the legal basis, namely rules and behavior. The regulatory component appears from a number of legal rules regarding the application of restorative justice in investigations that have been regulated in police regulations,

Keywords: Progressiveness; Fraud And Embezzlement; Restorative Justice.

\section{Introduction}

In the life of the nation and state, security is a determining factor in the implementation of a sovereign and authoritative government, which is the main condition supporting the establishment of a just, prosperous, prosperous and civilized civil society system based on the Pancasila and the 1945 Constitution of the Republic of Indonesia. Domestically, the Indonesian National Police conducts law enforcement efforts through the process of investigating and investigating a criminal act as regulated in Act Number 2 of 2002 on the Indonesian National Police.

Crimes of fraud and embezzlement are reported to be crimes that are very unsettling to the public and are mostly reported to the police. According to data from the National Police Headquarters, the number of reports of fraud cases dominated by online fraud (cyber crime) in the January-July 2019 period totaled 1,243 cases. ${ }^{4}$ The rise of fraud and embezzlement cases that occur in Indonesia is caused by many factors, including the advancement of science and technology which causes the forms

\footnotetext{
${ }^{1}$ Student of Master of Law, Universitas Islam Sultan Agung Semarang and Indonesian Police, email madesrintiri73@gmail.com

${ }^{2}$ Lecturer of Master of Law, Sultan Agung Islamic University (UNISSULA), Semarang

${ }^{3}$ Lecturer of Master of Law, Sultan Agung Islamic University (UNISSULA), Semarang

4 Andrea Lidwina, Penipuan Online, Kejahatan Siber yang Paling Banyak dilaporkan, in http://www.databoks.katadata.co.id, accessed December 1, 2019.
} 
or modus operandi of criminal acts of fraud to be diverse and difficult to trace. Substitution of material losses suffered by victims of fraud and embezzlement is a form of fulfillment of the rights of victims who have so far been ruled out in the criminal justice system. ${ }^{5}$ One of the victims' efforts to obtain compensation from the perpetrators is by conducting a peace agreement, but the process at the investigation level has not been clearly regulated.

As according to Prof. Satjipto Raharjo about his progressive legal theory, that the law must be able to provide happiness to its people. ${ }^{6}$ The basic nature of progressive law is that law is for humans, not humans for law. The law was created to achieve human well-being and happiness. ${ }^{7}$ The reality so far, the law is understood only limited to the formulation of the law, then implemented simply applying syllogism.

If the general law is forced to be applied just like that to certain events that are unique, then the law can risk causing social upheaval. Therefore the Police in the field discretion, so that in the hands of the police that the law can find its meaning. One of the efforts to be carried out in handling criminal acts is as an implementation of progressive legal concepts by police investigators, one of which is through the implementation of restorative justice in the criminal investigation process. Restorative justice (restorative justice) is the process of resolving criminal cases with the aim of achieving justice that is fully carried out and achieved by perpetrators, victims, and the wider community. ${ }^{8}$

Previously the National Police had issued several written provisions regarding the application of restorative justice in investigating criminal acts such as the Kabareskrim Telegram Letter number: STR / 583 / VII / 2012, but implementation in the field had constraints because the Telegram Letter was said to not be a strong legal umbrella that could protect the implementation of duties Police Investigator. Therefore, the National Police Chief of Police Tito Karnavian issued the Police Chief Circular Number: SE / 8 / VII / 2018, on the Implementation of Restorative Justice (restorative justice) in the settlement of criminal cases strengthened in Article 12 of Head Of Indonesia Police Regulation Number 6 of 2019 on Criminal Investigations, so that it becomes the legal umbrella of the National Police in the settlement of cases where there is peace, especially in the investigation of fraud and embezzlement cases.

One obstacle in the adoption of progressive law by the National Police is the existence of a hierarchy and a strong flow of positivism that rules out discretion as regulated by Act No. 2 of 2002 on the Indonesian National Police. ${ }^{9}$ Based on the description above, the writer is interested in researching with the title "Progressivity in the Handling of Fraud and Embezzlement Crimes by the Investigation Directorate of the General Criminal Investigation of the Central Java Regional Police".

\footnotetext{
${ }^{5}$ Usman Arifin, 2019, Asset Recovery Korban Tindak Pidana Penipuan dan Penggelapan Dalam Kaitannya Dengan Perlindungan Korban Kejahatan, Syiah Kuala University.

${ }^{6}$ Satjipto Rahardjo, 2010, Penegakan Hukum Progresif, Jakarta: PT Kompas Media. Nusantara, p. 37.

${ }^{7}$ Ibid, p. 61.

${ }^{8}$ Edi Setiadi, Kristian, 2017, Sistem Peradilan Terpadu dan Sistem Penegakan Hukum di Indonesia, Jakarta: Pranadamedia Group, p. 217

9 Jawade Hafidz, et al., 2015, Rekonstruksi Sistem Penyidikan Berbasis Hukum Progresif di Kepolisian Resort Kota Besar (Polrestabes) Semarang, Research Report, Kompolnas Mitra of the Faculty of Law, Unissula.
} 
The formulation of the problem in this study are: What is the process of handling fraud and / or embezzlement by the Central Java Regional Police Criminal Investigation Directorate? How is the progress of handling fraud and / or embezzlement by investigators from the Central Java Regional Police Criminal Investigation Directorate?

\section{Research Methods}

This study uses an empirical juridical approach. Specifications in this study are analytical descriptive research methods that are intended to systematically and accurately describe facts and characteristics about the population or regarding the field under study. ${ }^{10}$

The types of data used in this thesis are primary and secondary data. Primary data obtained from interviews with informants related toprogressive handling of fraud and embezzlement by the Central Java Regional Police Criminal Investigation Directorate, while secondary data is data obtained through literature studies to obtain conceptions, theories or opinions or theoretical foundations that are closely related to the issues discussed .

Method Data collection used is literature study and field study by conducting observations on the process of handling fraud and embezzlement by investigators and interviews with various parties related to the thesis title such as investigators and assistant investigators of the Central Java Regional Police Criminal Investigation Directorate.

\section{Results and Discussion}

\subsection{The Process of Handling Fraud and / or Embezzlement Criminal Acts by the Central Java Regional Police Investigator}

Based on data from the Bin Ops Ditreskrim Um Polda Central Java, for the last three years, namely the period 2017 to 2019, fraud and embezzlement are the most widely reported crime (Crime Total / CT) to the Central Java Regional Police. The number of cases reported (Crime Total / CT) is not comparable to the number of case settlements (Crime Clearence / CC) or have not reached the $100 \%$ settlement percentage, as seen from the case arrears (TTG) which is still quite high.

The high arrears on fraud and / or embezzlement cases are the lack of evidence, the absence of witnesses who have been summoned without clear reasons, the lack of fulfillment of the elements of the article, the alternation of case files due to incomplete investigation, and the existence of cases that have been revoked but the investigation has not yet been terminated.

Investigation of fraud and embezzlement is carried out by all units in the Central Java Regional Police Criminal Investigation Directorate. After receiving a police report of alleged fraud and / or embezzlement, the investigator and the auxiliary investigator then carry out the investigation process including the investigation stage; SPDP shipping; forced effort; examination; case title; settlement of case files; Submitting case files to the public prosecutor; the surrender of suspects and evidence; and

\footnotetext{
${ }^{10}$ Saifuddin Azwar, 2014, Metode Penelitian, Pustaka Pelajar, Yogyakarta, p. 7
} 
termination of the investigation.

According to Iptu Gorbacov, Officer III Unit III / Subdit III, fraud and / or embezzlement cases handled by investigators have different case characteristics. During the investigation process, there are times when peace occurs between the reporting party and the reported party. The reported party knows that he was reported by the reporting party to make a peace effort by paying compensation to the reporting party so that the case report is revoked and not proceeded to the realm of law. If there is a peace agreement, investigators from the Central Java Regional Police of the Dirreskrimum implement the implementation of restorative justice as stipulated in Head Of Indonesia Police Regulation No. 6 of 2019 on Criminal Investigations. ${ }^{11}$

One example of the application of restorative justice by investigators from the Directorate of Criminal Investigation of the Central Java Regional Police can be seen from the handling of Police Report Number: LP / B / 285 / VII / 2018 / JATENG / DIT RESCRIMUM dated July 15, 2018 about alleged embezzlement in positions and or falsification of letters allegedly carried out by Bro. AH as referred to in article 374 of the Criminal Code and or 263 of the Criminal Code handled by investigators Sud Dit III Ditreskrimum Central Java Regional Police. The case has been issued a Termination Letter of Investigation with the number: SPPP / 149.B / V / 2019 / Reskrimum on May 29 , 2019. During the investigation process there was a peace agreement between the reporting party and the reported party as set forth in the Credit Recognition Deed made before the Notary Public and the complainant filed a retraction of the Police Report because the problem was settled amicably.

With the retraction of the police report, the investigator conducted additional investigations to the reporting party and the reported party, then carried out the case title on May 21, 2019 in the Central Java Regional Police Directorate's Criminal Board meeting room. Based on the case recommendation, the investigator issued a Decree on Termination of Investigation Number: S.Tap / 149.A / V / 2019 / Reskrimum dated 29 May 2019 and Termination Letter of Investigation with number: SPPP / 149.B / V / 2019 / Reskrimum May 29, 2019.

Bripka Mustofa who is a supporting investigator handling the above case explained that, at that time the legal basis for terminating the investigation was the Circular of the National Police Chief Number: SE / 8 / VII / 2018 regarding the Implementation of Restorative Justice in Settling Criminal Cases due to Head Of Indonesia Police Regulation Number 6 of 2019 on Investigations Criminal Act did not take effect at that time. ${ }^{12}$ Since the issuance of the circular, investigators can resolve cases that have a peace agreement by implementing restorative justice.

The circular explains the formal and material requirements of a case that must be met in order to be resolved by applying restofratif justice. Criteria for cases that meet material requirements, for example cases that do not cause public unrest, do not have a conflict, have a statement by all parties that they do not object, and to the perpetrators there are limiting principles, namely the mistakes of the non-heavy perpetrators and non-recidivists. The fulfillment of formal requirements, namely the existence of a letter of request from both parties (the reporter and the reported

\footnotetext{
${ }^{11}$ Interview with Panit II Unit II Subdit III Iptu Gorbacov, March 3, 2020.

12 Interview with Bripka Mustofa's assistant investigator, 2 March 2020.
} 
party), the existence of a statement of peace, the Minutes of Supplementary Examination of the litigant, the recommendation of a special case title, the perpetrator does not object to responsibility or voluntarily provides compensation. ${ }^{13}$

Researchers' analysis related to the process of handling fraud and / or embezzlement from the stage of investigation and investigation as well as the cessation of the investigation of a peaceful case carried out by Central Java Police investigators in accordance with the Criminal Procedure Code, Circular of Police Chief Number: SE / 8 / VII / 2018 about on Application of Restorative Justice in Settling Criminal Cases as well as National Police Chief Regulation Number 6 Of 2019 on Criminal Investigations.

Based on research findings analyzed using the legal system theory according to Lawrence Meir Friedman that the handling of fraud and / or embezzlement by the Central Java Regional Police Investigator has fulfilled three elements in the legal system, namely structure, substance and culture law (legal culture). ${ }^{14}$ The structure (structure) in this case concerns law enforcement officials namely investigators and auxiliary investigators at the Directorate General of Criminal Investigation of the Central Java Regional Police, substance (substance), which involves laws and regulations governing the handling of fraud and / or embezzlement, namely the Criminal Code, the Criminal Code, Police Chief Circular Letter Number: SE / 8 / VII / 2018 on the Implementation of Restorative Justice in the Settlement of Criminal Cases as well as Regulation of the Police Chief Number 6 Of 2019 regarding Criminal Investigations.

The third element in the legal system theory according to Lawrence Meir Friedman is the culture / legal culture (legal culture) which is a human attitude towards law and the legal system, in which there are beliefs, values, thoughts and expectations. In addition to the community's legal culture, in addition to continuing the legal process in handling fraud and / or embezzlement cases, there are times when the community asks for a settlement because there has been peace between the two parties. The whistleblower's expectations have been fulfilled because the suspect is willing to return the loss so the reporter retracts the Police Report that has been made at the police force.

\subsection{Progressivity Handling of Fraud and / or Embezzlement Crimes by investigators of the Central Java Regional Police Criminal Investigation Directorate}

According to Prof. Satjipto Rahardjo, progressive law departs from empirical reality about its work inside law form society dissatisfaction and concern for performance and quality law enforcement in Indonesia on the end of the 20th century. Progressivism teaches that the law is not a king but as a tool to describe the basis of humanity which serves to give grace to the world and humans. ${ }^{15}$

\footnotetext{
${ }^{13}$ Police Chief Circular Letter Number: SE / 8 / VII / 2018, dated July 27, 2018 on the Implementation of Restorative Justice (restorative justice) in the settlement of criminal cases.

${ }^{14}$ Yesmil Anwar and Adang, 2009, Sistem Peradilan Pidana, Konsep, Komponen dan Pelaksanaannya dalam Penegakan Hukum di Indonesia, Bandung: Widya Padjajaran, p. 31-32.

${ }^{15}$ Satjipto Raharjo, 2009, Hukum Progresif Sebuah Sintesa Hukum Indonesia, Yogyakarta, Genta Publishing, p. Vi.
} 
Based on these assumptions, progressive legal criteria are: ${ }^{16}$

- Having a great goal in the form of human well-being and happiness;

- Contains a very strong moral content of humanity;

- Progressive law is a liberating law encompassing a very broad dimension that does not only move in the realm of practice but also theory;

- It is critical and functional, because progressive law does not stop seeing the deficiencies and find ways to fix them.

According to Satjipto Rahardjo, Progressive Law in principle departs from two basic components in law, namely rules and behavior. ${ }^{17}$ Between the system and humans requires an enlightening injection so that it becomes progressive. ${ }^{18}$ The legal actors can act progressively, but if the system is obstructed then the actions will be in vain and even become a guilty person (culprit). Vice versa, if the system and all software has been designed progressively, but if there are non-progressive human resources, the design cannot be realized optimally. ${ }^{19}$

According to the analysis of researchers, the progress of handling fraud and / or embezzlement by police investigators in the Central Java Regional Police is related to the application of restorative justice in investigating fraud and embezzlement cases that can be seen from the completion of investigating police reports of suspected criminal acts of fraud and or embezzlement on the basis of retracting police reports by the reporting party.

Besides that, the progress of handling criminal acts and fraud or embezzlement is associated with Progressive legal theory, starting from two basic components in law, namely rules and behavior. In terms of the components of the rules / rules, it can be seen from the issuance of several internal regulations of the National Police related to the implementation of restorative justice including the Kabareskrim Telegram Letter number: STR / 583 / VII / 2012 dated August 8, 2012, the Circular of the National Police Chief Number: SE / 8/2018 which was later strengthened in Article 12 of the Republic of Indonesia's Chief of Police Regulation Number 6 of 2019 on Criminal Investigations.

\section{Closing}

\subsection{Conclusion}

- The process of handling fraud and / or embezzlement from the stage of investigation and investigation as well as the cessation of the investigation of a peaceful case conducted by the Central Java Police investigator is in accordance with the Criminal Procedure Code, Circular Head of Police Number: SE / 8 / VII / 2018 about the Implementation of Restorative Justice In the Settlement of Criminal Cases and Regulation of the National Police Chief Number 6 Of 2019 on Criminal Investigations. Based on the legal system theory according to Lawrence Meir Friedman that the handling of criminal acts of fraud and / or embezzlement

\footnotetext{
${ }^{16}$ Satjipto Raharjo, 2009, op.cit, p. viii-viii.

${ }^{17}$ Satjipto Rahardjo, Membedah Hukum Progresif, Kompas Book, Jakarta, p. 4

${ }^{18}$ Satjipto Raharjo, 2009, Hukum Progresif Sebuah Sintesa Hukum Indonesia, Yogyakarta, Genta Publishing, p. 93.

${ }^{19}$ Ibid.
} 
committed by Investigators of the Criminal Investigation Unit of the Central Java Regional Police has fulfilled three elements in the legal system namely structure, substance and legal culture.

- The progress of handling fraud and / or embezzlement by the Central Java Regional Police Director of Criminal Investigation related to the implementation of restorative justice in criminal investigations. Besides that, the progressiveness in handling fraud and / or embezzlement is associated with Progressive legal theory, starting from two basic components of the law, namely rules and behavior. In terms of the component of rules / rules, it can be seen from the issuance of several internal regulations of the National Police related to the application of restorative justice including the Kabareskrim Telegram Letter number: STR / 583 / VII / 2012 dated August 8, 2012, Circular of the National Police Chief Number: SE / 8/2018 on the Implementation of Restorative Justice (restorative justice) which was later strengthened in Article 12 of the Regulation of the National Police Chief Number 6 of 2019 on Criminal Investigation. While the behavioral component can be seen from the initial study of the reception of pro-people police / complaints reports and the presence of investigators' attitudes in the form of courage / courage in the application of restorative justice in investigating criminal acts of fraud and or embezzlement.

\subsection{Suggestion}

- The implementation of restorative justice in investigating criminal acts by the National Police is one of the efforts of the National Police to progress in providing pro-people services to people who are victims of criminal acts. However, its implementation cannot guarantee the fulfillment of all victims' rights, especially victims of fraud and embezzlement, in the form of compensation received from perpetrators. Arrangements for compensation by perpetrators for victims of fraud and embezzlement must be firmly and clearly regulated by statutory regulations in Indonesia to ensure the fulfillment of victims' rights that have so far been ruled out in the criminal justice system.

- The need for a good storage and filing system for criminal case files that have been completed (complete files / P21 or investigation stopped) and cases that are still in the process of investigation at the Central Java Regional Police Criminal Directorate General, so as to facilitate the retrieval of data by law students will conduct legal research at the Central Java Regional Police.

\section{References}

[1] Edi Setiadi, Kristian, 2017, Sistem Peradilan Terpadu dan Sistem Penegakan Hukum di Indonesia, Jakarta: Pranadamedia Group.

[2] Jawade Hafidz, et al., 2015, Rekonstruksi Sistem Penyidikan Berbasis Hukum Progresif di Kepolisian Resort Kota Besar (Polrestabes) Semarang, Research Report, Kompolnas Mitra of the Faculty of Law, Unissula.

[3] Saifuddin Azwar, 2014, Metode Penelitian, Student Library, Yogyakarta.

[4] Satjipto Rahardjo, 2010, Penegakan Hukum Progresif, Jakarta: PT Kompas Media. 
Archipelago.

[5] Satjipto Raharjo, 2009, Hukum Progresif Sebuah Sintesa Hukum Indonesia, Yogyakarta, Genta Publishing.

[6] Satjipto Rahardjo, Membedah Hukum Progresif, Jakarta: Kompas Book.

[7] Yesmil Anwar and Adang, 2009, Sistem Peradilan Pidana, Konsep, Komponen dan Pelaksanaannya dalam Penegakan Hukum di Indonesia, Bandung: Widya Padjajaran

[8] Police Chief Circular Letter Number: SE / 8 / VII / 2018, dated July 27, 2018 on the Implementation of Restorative Justice (restorative justice) in the settlement of criminal cases.

[9] Andrea Lidwina, Penipuan Online, Kejahatan Siber yang Paling Banyak dilaporkan, in http://www.databoks.katadata.co.id, accessed December 1, 2019.

[10] Usman Arifin, 2019, Asset Recovery Korban Tindak Pidana Penipuan dan Penggelapan Dalam Kaitannya Dengan Perlindungan Korban Kejahatan, Syiah Kuala University. 